\title{
EDUCATIONAL OBJECTIVES MAKE OR BREAK THE QUALITY OF PATIENT CARE
}

PAPER PRESENTED AT A SYMPOSIUM TO CELEBRATE THE 25TH ANNIVERSARY OF THE DEGREE COURSE IN NURSING SCIENCE AT THE UNIVERSITY OF PRETORIA AND IN SOUTH AFRICA

\section{CHARLOTTE SEARLE}

\section{OPSOMMING}

Onderwys moet altyd 'n doel voor oë hou en die doel van verpleegonderwys is pasiëntsorg van 'n hoẻ gehalte. Duidelike doelstellings dien as wegwysers vir die onderw yser en student.

Die kriteria van 'n hoë peil van versorging ontstaan uit die waardes van die samelewing. Onderrigdoelstellings berus ook op waardes en moet aan die hand van die waardesisteem van die samelewing waarin die beroep funksioneer, opgestel word. Verpleegonderwys moet dus vanuit die breè behoeftes van die samelewing beskou word, dit moet aan die student sin vir haar lewe gee en haar sosialiseer in die rol van verpleegkundige.

Onderrigdoelstellings wat streef na'n hoë gehalte sorg sal nie bereik word indien foutiewe onderrigstrategieê, soos die funksionele toewysing in kliniese praktika, gebruik word, en daar nie aandag geskenk word aan onderrigmetodes wat studentebetrokkenheid in die leersituasie bevorder nie.

Die pasiënt is die primêre bron van inligting vir die bepaling van doelstellings vir verpleegonderwys en dit is dus noodsaaklik dat onderwysers by pasiëntesorg betrokke moet wees. Verpleegonderwys is aan die samelewing verantwoordelik vir die gehalte sorg wat gelewer word en die grondslag van aanspreeklikheid is in geldige doelstellings geleë.

\section{Semper aliquid certi propendum est (always some certain end must be kept in view)}

\section{INTRODUCTION}

A most important criterion in nursing education is that a definite end must be kept in view. This end purpose or terminal outcome is the concept of Quality nursing care.

Educational objectives in nursing education are the road signs which help both teacher and student to chart their way through the mass of social, legal, ethical and scientific material that has to be mastered by the student and her teachers before reaching their ultimate goal - the preparation of a professional practitioner who is competent and willing to provide quality care within a total patient-care context. The rationale underlying educational objectives, the way they are formulated and implemented and their outcomes evaluated and also the philosophy supportive to the whole process will make or break the quality of patient care provided by students and by qualified practitioners.

The purpose of this article is not to tell the reader how to identify, for- mulate, implement and evaluate educational objectives. Rather, some questions are asked for all to ponder over.

How do we determine educational objectives for quality care when the concept quality care has little relevance to the way in which some centres prepare the students to provide clinical care? How can there be quality care when the patient is depersonalised by providing his treatment and care on an assembly line or functional assignment basis, initially designed to cope with a crisis situation during World War II? How can there be quality care when the concept of total patient care is nullified by the functional assignment of students in the clinical care situation and where the emphasis is on things and procedures instead of on the total needs of a patient? How do we set objectives in such a learning situation and how do we evaluate them? Do we set objectives to meet examination requirements, or do we do so to provide competent nurse practitioners who are committed to provide quality care? How do we determine objectives with- in a nursing care plan when there is no such plan? How do we relate the objectives to outcomes when we derail the process with a functional teaching/learning approach?

The national aims and objectives of nursing education and the philosophy of the South African Nursing Council require nurse education and training to ensure that quality nursing in a preventive, promotive, curative and rehabilitative context is available to man from before birth and throughout his lifespan, within the parameters of societal needs and expectations, and the socio-economic and cultural constraints of the South African community.

The national aims and objectives enshrined in the directives for the various curricula of the South African Nursing Council are the minimal standards of nursing education for safe nursing practice in the particular field. They are the common denominators for the various nursing schools which are supposed to clothe the skeletons of national curricula and directives with the flesh and blood and sinews of 
vibrant courses tailored not only to meet national, but also regional, and local needs, as well as the needs of the neophytes who enter the nursing education programmes in the particular area.

\section{OBJECTIVES REST UPON VALUES}

The specific educational objectives are expected to be determined within the broad framework of the societal needs, as evinced in the national curricula and directives. This presupposes that they are identified and implemented within the philosophy, ethics, laws and knowledge, skills and attitudes regarded as desireble for quality practice, as well as within the broad needs of society and the individual needs of the patient and the student. If the objectives are technically and assembly line oriented, there cannot be quality care in the true sense of the word.

Objectives are value bound, so if objectives are to be meaningful they have to be formulated within the value system which has evolved over a long span of time from social, medical, individual and nursing needs and actions. In other words, we have to know what we mean by quality care, what our standards are, why we have these standards, how these can be attained, how the student is educated and trained to meet these standards and what value judgements have to be made when evaluating her competency during, and on completion of her course. We have to ensure that those concerned with the educational process are true role models for the student, patient and society at large.

Davies stresses the fact that all objectives rest upon an assumption or underlying complex of values $(5, \mathrm{p} 3)$. These lie at the heart of the planning process $(5, \mathrm{p} 4)$. Note that it is the values that are central to the issue. These two concepts, values and planning, are crucial elements in the concept that educational objectives make or break the quality of patient care. To translate values into action requires meticulous identification of objectives and careful planning for the implementation of objectives.

\section{QUALITY PATIENT CARE - A VALUE CONCEPT}

Quality patient care reflects a value concept in a particular system of health care in a particular society Medical, nursing and social philosophy, political ideology, administrative policies and social development create certain social expectations educationally, economically and tech- nologically, and help to determine what is meant by quality care in a specific society. There is no universally held concept of what constitutes quality patient care. However, in the South African context we have certain criteria which determine what is meant by quality care. These criteria are the parameters within which we have to identify and implement objectives.

\section{CRITERIA FOR QUALITY CARE - SOUTH AFRICAN PERSPECTIVE}

The criteria for quality care have emerged from a vast mix of concepts held by committed nurses, doctors, administrators and the public at large. The individual and the society of which he forms part appear to judge quality nursing by a variety of factors. The safety of his person, his property and his name looms large. But the quality of care goes beyond this legal premise in the provision of health care. Safety is paramount, but the individual and society expect nursing to be timeous, ethical, knowledgeable, accurate, skilful, humane, empathic and sympathetic with due regard for the dignity and individuality of the recipient of such care, irrespective of race, colour, creed, social, cultural, political and economic status. The patient expects care that revolves around his own specific needs in circumstances where he is the centre of all activities. The patient and his needs must form the pivot of the care. Society and the individual patient expect responsibility and accountability from the nurse. Both expect the nurse to provide the care within a value system as well as a scientific system.

Only individualised and total care, provided by persons who understand and respect all the nuances of physical, social and emotional needs in the health-care situation as a whole and of a particular recipient of health care, can meet these demands. It cannot be met by a functional assignment approach where the nurse is concerned with various aspects of procedures and not with the complete spectrum of human needs that bedevil the particular health-care situation.

\section{WHERE ARE THE CRITERIA AND OBJECTIVES FOR QUALITY CARE GENERA- TED?}

The educational objectives aimed at providing quality care are generated at and evolve from the same source as the criteria. The objectives have to ensure that the criteria are met. Specific educational objectives can never be divorced from the broad aims and goals of the programme. This is where we frequently go wrong, and this is where a functional approach in our teaching sabotages the basic meaning of nursing as spelt out by Henderson, Orem, Levine, Rogers, King and others, and as manifested in $A$ South African Nursing Credo.

Nursing in its true sense, and hence the educational objectives for the teaching of the discipline, presupposes a depth of knowledge about the health needs, views, cultural values, economic and human resources and political will of society. It also presupposes a depth of understanding of the developmental stages of man as a biological and social being, of medical science and technology, of nursing science and philosophy, its aspirations and potential and of the developmental stages, intellectual potential, philosophy, norms and values and aspirations of the student nurse. Both in her student years as well as in her life as a registered nurse practitioner, the student nurse has to supply a realistic, holistic interdigitation of a mass of scientific detail from a variety of disciplines to provide humane, empathic, sympathetic, individualised, scientific nursing care. Within a framework of nursing philosophy, human needs, scientific nursing knowledge, psychomotor and affective skills, laws, ethics and administrative policies and practices, the mass of basic material has to be transformed into quality patient care.

Clear objectives that take all the foregoing into consideration have to be devised to serve as the landmarks past which the student wends her way through the learning content of the discipline. In a system where teaching and clinical practica are frequently concerned with things in general and not with the variety of human needs that bedevil the particular health-care situation, both teacher and student may lose their way to the detriment of patient care.

\section{INEFFECTIVE TEACHING MODALITIES NEGATE OB- JECTIVES}

If our clinical practice system is functional assignment dominated, how valid are our objectives for ensuring quality care? It is not only the system of teaching by functional assignment that defeats the identification and implementation of objectives which could ensure quality care. Coupled with this is the problem of other teaching approaches which weaken student involvement and the realisation of objectives.

It is a widely held assumption that much of nurse teaching at present is done in the classical perspective, which consists overwhelmingly of lec- 
tures within an autocratic, conservative, subject-emphasised, teacherdominated, other-directed, over-disciplined, skill-oriented atmosphere. Far too little or sometimes no attention is given to such factors as creativity, personal and professional growth, and self-fulfilment of the individual student, to the nurturing of enquiring minds, to participation in the instructional system and to the end purpose of it all. This end purpose is not the examination at the end of the course, but the provision of quality health care to man from before birth and throughout all the stages of his life. Unless the end purpose, the underlying values, the scientific content and the potential of the student are seen as a whole, and unless form and substance is given to the educational process by careful identification of learning needs, formulation of explicit objectives, careful definition of the rationale for specific objectives and meaningful interpretation of objectives, the educational system will at best be mechanistic. How can the student know the path she has to follow unless she encounters the clearly marked milestones in the form of realistic objectives? How can she progress from the simple to the complex unless the objectives are clearly defined, and how can she ever cope with the reality of clinical nursing if she has not passed specific milestones by mastering the objectives at each of the various stages of the curriculum before being confronted with the reality of providing skilled care to seriously ill patients.

\section{OBJECTIVES ARE IN- FLUENCED BY HOW WE SEE NURSING EDUCATION}

How do we see nursing education? Is it merely the preparation of certain categories of nursing personnel at basic, post-basic and in-service educational levels? Or is it something more?

As a comitted nurse teacher the author believes that:

- nursing education is inescapably a moral undertaking. Those who see no meaning in nursing and nursing education have missed this basic truth. The aim of society in providing education and training for nurses is to supply a service to society. Its purpose is to ensure that a cadre of citizens with specialised knowledge and skills are available to provide competent and humane nursing care within the parameters of the ethical norms of the profession and the legal, political, economic, social and cultural constraints of society. These strands, which interpret society's aims, weave throughout the educational programme. 'They have short-term as well as long. term objectives which generally span decades into the future. Every aspect of the learning content has to be seen in this perspective, so all learning objectives must relate to these. This is the cement which binds all the aspects of the course into a meaningful whole;

nursing education is not a mere preparation of students for performing tasks in the clinical situation or for future professional practice. It is far more than that, it is life itself, for every learning objective should have two ends in view, namely quality care for a human life in need of health care, and personal and professional selfrealisation and an attainment of meaning in life. The attainment of meaning in life is the most important formative influence in the student's professional preparation. This will motivate her to provide quality nursing care;

- nurses are decision-makers and problem-solvers. Appropriateness of knowledge, skills and attitudes are key issues in determining objectives. Receiving their professional preparation in an atmosphere where the educational objectives support the aims of society, professional goals and total patient care, and where clear identification of objectives underlies every dimension of the learning process, is part of the preparation nurses need for decision-making and problem-solving. Early in their programme they have to learn that identifying objectives is crucial to the utilisation of resources and to all effective nursing action;

- the student nurse has to be socialised into the role of a nurse. The influence of effective role models and active involvement in all the nuances and dimensions of the nursing education process is important. Questioning and critical evaluation of the rationale underlying social as well as nursing care objectives are vital formative influences in role socialisation. Quality care does not only depend on knowledge and psychomotor skills, it is inextricably linked with attitudes towards role fulfilment. If role socialisation occurs smoothly because educational objectives are realistic and have been carefully defined, and if the teaching objectives are reinforced by the precept and example of effective role models, the development of desirable attitudes by the student will reinforce the learning process, will serve to make learning objectives and activities meaningful, and will in turn generate the drive to ac quire the essential knowledge and skills to meet the exacting standards envisaged by the concept quality patient care. It all depends to what extent the ains, goals and specific objectives of the course provide meaning to the personal and professional life of the student.

\section{CLEAR OBJECTIVES NEEDED}

Only by the clear definition of objectives will the student know what she has to learn, why she has to do so and when and how she has to do it. This is a debt owed to every student. The hit-and-run system of clinical teaching in many nursing schools is a classic example of the lack of identification of educational objectives, and of the lack of interdigitation of values and scientific content, as well as of the lack of moral obligation both in nurse teaching and to the patient who is a recipient of the student's care.

The prejudices manifested about the clear identification of learning objectives in nursing education probably flow from a lack of knowledge and from the rejection of the behaviouristic concepts that dominate the determination of educational objectives to a marked degree. Davies believes that the dogma which has been associated with specific behavioural objectives.. has often blinded us either to their in herent potential, or to their inbuilt limitations. He believes that they should not be seen as a universal remedy or panacea for all the ills in contemporary education, but rather as essential tools to guide and to help us identify the needs of society, patients and the learner. Careful identification of objectives leads to clarity in teaching and learning. It does not mean that the richness of teaching and learning need be restricted for the sake of this essential clarity, nor that romance in teaching and learning be sacrificed for the sake of clarity. (5, preface) Davies maintains that objectives must be put in perspective, and then be handled in a sensitive, creative manner... They Should be used as a resource for teaching and learning, rather than a set of blinkers or restrainers. (5, preface). Popham links up with Davies in saying that the appropriateness of objectives lies in their clearness, intelligibility, and explicitness which are such virtues in teaching. $(6, \mathrm{p} 32)$ 
Inherent in the need for a clear statement of objectives for quality care lies the concept of accurate measurement and evaluation, or output appraisal, not only of student performance but also of teaching performance. Overshadowing both these components is the question of results. How does all this contribute to quality patient care? Does the health care available to the individual and to society at large meet needs and expectations? Many of the technical aspects and most of the knowledge of nursing can be measured relatively accurately. However, the complex activities, attitudes, legal and ethical concepts and applied scientific facts that form the matrix of nursing care requires an evaluative approach, which is measurement plus judgement formulated in terms of objectives and values. According to Popham some of our goals and objectives are currently unassessable. Many attitudes and a predisposition to certain actions and standards of accountability will manifest only after some time has elapsed. $(6, p 24)$ This we accept. If we lay a sound foundation we could have reasonable expectations for the future.

\section{CLINICAL CONTACT NECES- SARY FOR DETERMINING OBJECTIVES}

How can objectives that will contribute to the quality of patient care be developed?

The primary source for identification of educational objectives to provide quality nursing care is the patient himself. Patient health needs and the variables affecting these needs and patient problems in coping with health needs and the variables affecting these needs and patient problems in coping with health needs lie at the very heart of a nursing curriculum and therefore at the heart of educational objectives in the nursing education system. The patient and all the dimensions of his health needs and the problems related thereto are the raison d'etre for a nursing curriculum.

Teachers of clinical nursing and of the subjects supportive of this cannot determine the educational objectives which ensure quality care if they are divorced from practice. Such teachers only draw on secondary sources to give form and meaning to their teaching programmes. They rely exclusively on literature and on discussions with their peers to formulate their educational objectives. They are hemmed in by imagined constraints of the national curriculum. Because the reality of the patient care situation does not leaven their thinking, the educational programme loses its punch and its purpose is misdirected. A tertiary source which is a menace to any educational programme is the bygone experience of the teacher which has had no new inputs either from reading, discussion or from clinical experience. Although such a teacher may be able to spell out the objectives of a course and of its learning experiences, the impact is negative because it lacks the reality of the ever-changing and demanding patient care situations.

Society's impact, factors which threaten health, the ways of coping with these threats, the human needs of the patient and the potential, the aspirations and the abilities of nurse and teacher meet at the patient's bedside, his home, school or work situation. His health needs constitute the reason for it all. Yet teaching the intricate subject of nursing care is attempted by teachers who stay away from the clinical situation and leave students to cope with the clinical learning situation with a minimum amount of guidance. Without both teacher and nurse being involved in patient care, goal-directed educational objectives cannot be determined. In fact, because of misdirection, the goal of the newly qualified nurse frequently appears to be nursing the administrative procedures and not the patient.
This is described as a widespread phenomenon by many astute nurse observers. Could it possibly be that the absence of scientifically based, clearly defined educational objectives in many of our nursing schools has caused our educational programmes to misfire with a resultant loss in the qualitative, and in many instances also the quantitative aspects of nursing care?

\section{ACCOUNTABILITY}

Accountability in nursing education is of primary importance. Popham says that the teacher must produce evidence regarding the quality of his or her teaching, usually in terms of what happens to the pupils then standing ready to be judged on the basis of the evidence. $(6, p) 70)$ The evidence in nursing is quality nursing care. The taxpayer has made the nurse teacher responsible for ensuring that the aims of society for quality nursing care are realised.

Fundamental to accountability are clear aims, goals, objectives and subobjectives in the presentation of the educational programme. The student, the teacher, the assessor of outcomes and society will know exactly where they stand when the nursing curriculum is seen in a broad and total perspective and the objectives are clearly and appropriately defined in order to ensure that the standards set for quality care can be realised. Quality care requires clearly defined standards and accountability, and basic to these are clear-cut and appropriate educational objectives.

\section{GENERAL REFERENCES}

1. Burns, $R$. New approaches to behavioral objective Brown. Dubuque. 1972. 2nd Ed.

2. Carroll, A.D.; Duggan, J.E.; Etchelle, R. Learnin by objectives. Hutchingon. Landon. 1978 .

3. Clark, D.C. Using inatructional objectives in teaching. Scott Foresman. London. 197

(um and ingtruction in numing. Little Brown. Boston. 1973

B. Davies, I. Objectives in curriculum deaign McGraw-Hill. London. 1976. Fearon. Belmont. 1873 . 7. Popham, W.J.; Baker, E.L. Establishing instructional goals. Prentice-Hall. Englewood-Cliffi. 1870. 